\title{
Kinetics and adsorption studies of lead (II) onto activated carbon using low cost adsorbents
}

\author{
Kibami D.* \\ Department of Chemistry, Kohima Science College, Jotsoma-797002, Nagaland, India \\ Received: 21/11/2017, Accepted: 07/05/2018, Available online: 02/08/2018 \\ *to whom all correspondence should be addressed: e-mail: danielkibs80@yahoo.co.in
}

\begin{abstract}
The removal of Lead (II) from aqueous solutions using Fagopyrum esculentum Moench (Buckwheat) and Bambusa vulgaris (common bamboo) as adsorbents was investigated. The effects of various experimental parameters such as initial concentration, contact time and $\mathrm{pH}$ have been studied using batch adsorption technique. All the Adsorption isotherm models fitted well with the adsorption data. However, Freundlich isotherm displayed a better fitting model than the other two isotherm models due to high correlation coefficient $\left(R^{2}\right)$. This indicates the applicability of multilayer coverage of the $\mathrm{Pb}$ (II) on the surface of adsorbent. The adsorption kinetics was studied using four simplified models and it was found to follow the pseudo-second-order kinetic model which confirmed the applicability of the model. The adsorption mechanism was found to be chemisorption and the rate-limiting step was mainly surface adsorption.
\end{abstract}

Keywords: Lead; Batch method; Adsorption; Multilayer

\section{Introduction}

Water pollution caused by heavy metals has posed a significant threat to the environment and public health because of their toxicity, accumulation in the food chain and persistence in nature (Bahadir et al., 2007). Lead, an element which has been used for years, can be regarded as a longstanding environmental contaminant. All the chemicals/compounds containing lead are considered as cumulative poisons that usually affect the gastrointestinal track, nervous system and sometimes both (Nadeem et al., 2005). According to the US Environmental Protection Agency (EPA) the permissible level for lead in drinking water is $0.05 \mathrm{mg} \mathrm{L}^{-1}$ (Bhattacharjee et al., 2003) and that of Bureau of Indian Standards (BIS) is $0.01 \mathrm{mg} \mathrm{L}^{-1}(\mathrm{BIS}, 1981)$. Therefore, a very low concentration of lead in water is very toxic (Bhattacharjee et al., 2003). The chief source of lead in water is from the effluents of processing industries. Lead is also used in many commercial products like storage batteries and plastic water pipes. Therefore, the safe and effective disposal of lead in wastewater poses a challenge since lead does not degrade in environment like organic pollutants (Jalali et al., 2002; Gupta et al., 2011; Sekar et al., 2004). At present, various methods like chemical precipitation, electrochemical reduction, ion exchange, reverse osmosis, membrane separation, and adsorption have been developed to remove $\mathrm{Pb}^{2+}$ from wastewater (Conell et al., 2008; Acharya et al., 2009; Ricordel et al., 2001; Saeed et al., 2005; Doyurum et al., 2006). Adsorption of activated carbon has been shown to be very effective for the removal of toxic metal ions from aqueous solutions. However, the high cost of activated carbon limits its use especially in developing countries. This has led for the search of activated carbons from cheap and renewable sources by various researchers over the years (Ferro et al., 1990; Sohail and Qadeer, 1997; Netzer and Hughes, 1984). Therefore, for the present study we have chosen the precursor for synthesis of activated carbon which is from common bamboo and common buckwheat plant. It can be an alternative for the adsorption of heavy metals from aqueous solution since they are abundant in nature, inexpensive, require little processing and are effective materials. These waste materials have little or no economic value and often creates disposal problem.

\section{Materials and methods}

\subsection{Synthesis of absorbents}

For the synthesis of adsorbents, the raw materials, i.e., stems and leaves of Bambusa vulgaris (BVC), Fagopyrum esculentum Moench (FEMC) plants, were collected and sun-dried for a few days. The dried materials were crushed manually into smaller pieces and were packed in clean stainless-steel containers and put in a Muffle furnace at $650 \pm 20{ }^{\circ} \mathrm{C}$ for $4 \mathrm{~h}$ in a uniform nitrogen flow wherein carbonization was done. The already carbonized materials were then grounded into fine powder with mortar and pestle and washed with distilled water to remove impurities and dried in hot air oven at $110{ }^{\circ} \mathrm{C}$. The dried carbons were then pulverized in the planetary Ball Mill at $600 \mathrm{rpm}$ for around $10 \mathrm{~min}$ to obtain uniform size. Once the carbons were prepared, surface modification was done by the following process.

\subsection{Surface modification of the synthesized adsorbents.}

Fifteen grams of the prepared carbon was taken in a $500-$ $\mathrm{ml}$ beaker, and $0.1 \mathrm{~N} \mathrm{HNO}_{3}$ solution was gradually added until the sample was fully submerged. The mixture was then thoroughly shaken for $3 \mathrm{~h}$ in a rotary shaker. 
Thereafter, it was filtered using Whatman No. 42 filter paper. The carbon was washed with double-distilled water several times for removal of excess of acid to maintain the $\mathrm{pH}$ of the carbon between 6.9 and 7 and then dried in an oven at $110^{\circ} \mathrm{C}$. After complete drying, the dried activated carbons were stored in airtight containers for further study. Similar procedure is followed for surface modification of carbon with $0.1 \mathrm{~N} \mathrm{H}_{3} \mathrm{PO}_{4}$.

\subsection{Preparation of lead (II) solution}

Stock solution of $\mathrm{Pb}(\mathrm{II})$ was prepared $(1000 \mathrm{mg} / \mathrm{l})$ by dissolving required amount of $\mathrm{Pb}\left(\mathrm{NO}_{3}\right)_{2}$ in acidified double distilled water. The stock solution was diluted with distilled water to obtain desired concentration ranging from 5 to $45 \mathrm{mg} \mathrm{L}^{-1}$. All the chemicals used were of analytical reagent grade. The lead (II) ions is analysed by atomic absorption spectroscopy at $283.3 \mathrm{~nm}$, using graphite furnace Analytikjena Vario- 6 . The calibration is carried out versus an aqueous standards curve.

\subsection{Adsorption studies of lead on activated carbons by batch method}

In order to understand the adsorption behavior of lead, various experimental parameters have been investigated using batch adsorption experiments. The effect of initial concentration is studied by varying lead concentrations between 5-45 $\mathrm{mg} \mathrm{L}^{-1}$. The effect of contact time was studied by varying the agitating time (range:2-240 minutes) at fixed optimum initial concentration of lead $\left(20 \mathrm{mg} \mathrm{L}^{-1}\right)$ with optimum dose of adsorbents $\left(0.25 \mathrm{~g} \mathrm{~L}^{-1}\right)$ and also the effect of $\mathrm{pH}$ was studied ranging from 2-5.5. The percentage removal of the lead and the amount of lead adsorbed were calculated by the following equations.

$$
\begin{aligned}
& \text { Percentage removal }=100 \frac{\left(C_{i}-C_{f}\right)}{C_{i}} \\
& \text { Amount absorbed }\left(q_{e}\right)=\frac{\left(C_{i}-C_{f}\right) V}{M}
\end{aligned}
$$

where $C_{i}$ and $C_{f}$ are the initial and final equilibrium solution concentrations of the lead $(\mathrm{mg} / \mathrm{L}), \mathrm{V}$ is the volume of the solution ( $\mathrm{L}$ ) and $\mathrm{M}$ is the mass of the activated carbon ( $\mathrm{g}$ ). The data obtained have been analyzed for adsorption isotherms models and Intraparticle diffusion model.

\section{Results and discussion}

\subsection{Effect of initial concentration:}

Effect of initial varying concentration of $\mathrm{Pb}$ (II) ions showed that the percentage adsorption decreases with increase in initial concentration of the adsorbate. This decrease in $\mathrm{Pb}$ (II) ions uptake capacity with increase in initial metal concentration may be due to the formation of clusters of carbon particles resulting in decreased surface area (Montanher et al., 2005; Chen and Wu, 2004). The variation of percent removal of lead with increasing Initial concentration is shown in Fig. 1. The data reveals that under identical experimental conditions, the order of adsorption capacity of the various adsorbents is as: $\operatorname{BVC}\left(\mathrm{HNO}_{3}\right)>\mathrm{BVC}\left(\mathrm{H}_{3} \mathrm{PO}_{4}\right)>\mathrm{FEMC}\left(\mathrm{HNO}_{3}\right)>\operatorname{FEMC}\left(\mathrm{H}_{3} \mathrm{PO}_{4}\right)$.

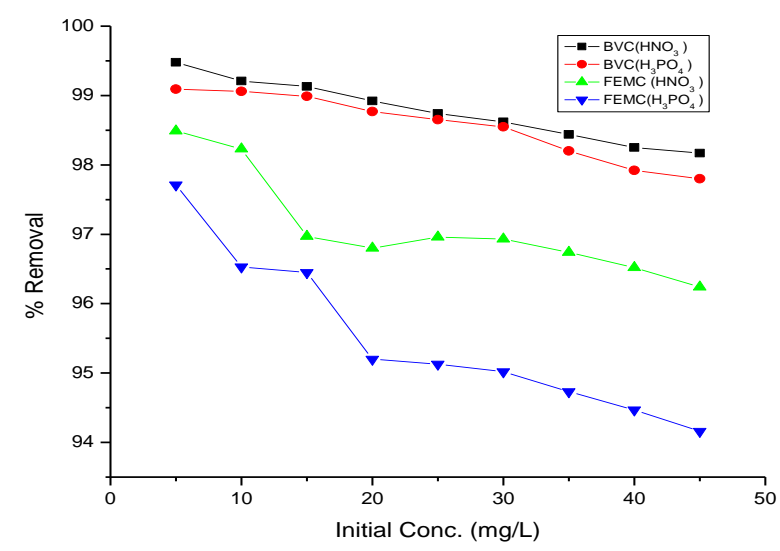

Figure 1. Variation of percent removal of lead with increasing initial concentration.

\subsection{Adsorption isotherm}

The relationship between the amount of a substance adsorbed per unit mass of adsorbent at constant temperature and its concentration in the equilibrium solution is called the adsorption isotherm (Feng et al., 2004). Various adsorption isotherm models are employed in this study to describe the experimental adsorption isotherm (Langmuir, 1918; Freundlich and Helle, 1939; Temkin, 1940).

\subsubsection{Langmuir adsorption model}

The Langmuir adsorption model is the most common model used to quantify the amount of adsorbate adsorbed on an adsorbent as a function of partial pressure or concentration at a given temperature. It suggests the formation of monolayer adsorption and also the surface is energetically homogeneous (Feng et al., 2004). The Langmuir equation which is valid for monolayer adsorption onto a surface is given below

$$
\mathrm{q}_{\mathrm{e}}=\frac{\mathrm{Q}_{\max } \mathrm{K}_{\mathrm{L}} \mathrm{C}_{\mathrm{e}}}{1+\mathrm{K}_{\mathrm{L}} \mathrm{C}_{\mathrm{e}}}
$$

Where $C_{e}$ is the equilibrium metal ion concentration $(\mathrm{mg} / \mathrm{l})$, $q_{\mathrm{e}}$ the amount of lead adsorbed at equilibrium $\left(\mathrm{mg} \mathrm{g}^{-1}\right)$ and $Q_{\max }\left(\mathrm{mg} \mathrm{g}^{-1}\right)$ and $K_{L}\left(\mathrm{~L} \mathrm{mg}^{-1}\right)$ are Langmuir constants related to adsorption capacity and energy of adsorption, respectively.

The essential characteristics of the Langmuir equation can be expressed in terms of a dimensionless constant called separation factor ( $R_{L}$, also called equilibrium parameter) which is defined by the following equation (Ozacar and Sengil, 2004; Mall et al., 2006; Crini et al., 2007).

$$
\mathrm{R}_{\mathrm{L}}=\frac{1}{1+\mathrm{K}_{\mathrm{L} \mathrm{C}_{\mathrm{i}}}}
$$

where $C_{i}\left(\mathrm{mg} \mathrm{L}^{-1}\right)$ is the initial adsorbate concentration and $\mathrm{K}_{\mathrm{L}}\left(\mathrm{L} \mathrm{mg}^{-1}\right)$ is the Langmuir constant related to the energy of adsorption. The value of $R_{L}$ indicates the shape of the isotherms to be either unfavorable $\left(R_{L}>1\right)$, linear $\left(R_{L}=1\right)$, favourable $\left(0<R_{L}<1\right)$ or irreversible $\left(R_{L}=0\right)$, the results from Table 1 shows $R_{L}<1$ in all the cases, this indicates a favorable isotherm for the adsorbents used in this study. 
Table 2 compares the adsorption capacity of different types of adsorbents used for removal of $\mathrm{Pb}^{2+}$ ions. The most important parameter to compare is the Langmuir $Q_{\max }$ value since it is a measure of adsorption capacity of the adsorbent. The value of $\mathrm{Q}_{\max }$ in this study is larger than those in most of previous works. This suggests that $\mathrm{Pb}^{2+}$ ions could be easily adsorbed on the synthesized adsorbents.

Table 1. Adsorption isotherm parameters for $\mathrm{Pb}^{2+}$ adsorption on synthesized adsorbents.

\begin{tabular}{ccccc}
\hline Frendulich Isotherm & $\mathbf{R}^{\mathbf{2}}$ & Log K & $\mathbf{1 / n}$ & $\mathbf{n}$ \\
\hline BVC $\left(\mathrm{HNO}_{3}\right)$ & 0.999 & 0.931 & 0.601 & 1.654 \\
\hline BVC $\left(\mathrm{H}_{3} \mathrm{PO}_{4}\right)$ & 0.991 & 0.484 & 0.625 & 1.596 \\
\hline FEMC $\left(\mathrm{HNO}_{3}\right)$ & 0.998 & 0.623 & 0.696 & 1.443 \\
\hline FEMC $\left(\mathrm{H}_{3} \mathrm{PO}_{4}\right)$ & 0.993 & 0.362 & 0.653 & 1.517 \\
\hline Langmuir Isotherm & $\mathbf{R}^{\mathbf{2}}$ & $\mathbf{Q}$ max & $\mathbf{K} \mathbf{L}$ & $\mathbf{\mathbf { R } _ { \mathbf { L } }}$ \\
\hline BVC $\left(\mathrm{HNO}_{3}\right)$ & 0.996 & 57.714 & 0.942 & 0.179 \\
\hline BVC $\left(\mathrm{H}_{3} \mathrm{PO}_{4}\right)$ & 0.933 & 30.196 & 0.585 & 0.254 \\
\hline FEMC $\left(\mathrm{HNO}_{3}\right)$ & 0.978 & 56.497 & 0.797 & 0.202 \\
\hline FEMC $\left(\mathrm{H}_{3} \mathrm{PO}_{4}\right)$ & 0.879 & 14.088 & 0.135 & 0.605 \\
\hline Temkin Isotherm & $\mathbf{R}^{\mathbf{2}}$ & $\mathbf{B}$ & $\mathbf{B}$ & $\mathbf{A} \mathbf{T}$ \\
\hline BVC $\left(\mathrm{HNO}_{3}\right)$ & 0.962 & 0.417 & 2.423 & 360.836 \\
\hline BVC $\left(\mathrm{H}_{3} \mathrm{PO}_{4}\right)$ & 0.984 & 0.364 & 1.772 & 131.863 \\
\hline FEMC $\left(\mathrm{HNO}_{3}\right)$ & 0.934 & 0.329 & 1.464 & 92.224 \\
\hline FEMC $\left(\mathrm{H}_{3} \mathrm{PO}_{4}\right)$ & 0.945 & 0.353 & 1.392 & 50.912 \\
\hline
\end{tabular}

\subsubsection{Freundlich adsorption model}

Freundlich isotherm is an empirical equation describing the heterogeneous adsorption and assumes that different sites with several adsorption energies are involved (Sekar et al., 2004; Crini et al., 2007). The linear form of the Freundlich equation is shown below.

$$
\log q_{e}=\log k+\frac{1}{n} \log C_{e}
$$

Where $C_{e}$ is the equilibrium metal ion concentration ( $\left.\mathrm{mg} \mathrm{L}^{-1}\right), q_{\mathrm{e}}$ the amount of lead adsorbed at equilibrium (mg $\mathrm{g}^{-1}$ ), $K$ and $1 / n$ are the Freundlich constants incorporating all the factors effecting adsorption capacity, an indication of favorability of metal adsorption onto adsorbent (Freundlich and Helle, 1939). The slope $1 / n$ gives adsorption capacity and intercept log $\mathrm{K}$ gives adsorption intensity from the straight portion of the linear plot obtained by plotting log $q_{e}$ versus $\log C_{e}$ gave a straight line with slope of $1 / n$, Freundlich constants $K_{\mathrm{F}}$ and $n$ were also calculated and are listed in Table 1.

Table 2. A comparison of the adsorption capacity of the synthesized adsorbents with the literature data.

\begin{tabular}{|c|c|c|c|}
\hline Adsorbent & Activating agent & $Q_{\max }\left(\mathrm{mg} \mathrm{g}^{1}\right)$ & References \\
\hline Rice husk & Tartaric acid & 120.48 & Wong et al., (2003) \\
\hline Sawdust (Pinus sylvestris) & Formaldehyde in Sulfuric acid & 9.78 & Taty-Costodes et al., (2003) \\
\hline Peanut husk & Sulfuric acid & 29.14 & Li et al., (2006) \\
\hline Banana stem & Formaldehyde & 91.74 & Noeline et al., (2005) \\
\hline Spent grain & Sodium hydroxide & 35.5 & Low et al., (2000) \\
\hline Alfalfa biomass & Sodium hydroxide & 89.2 & Tiemann et al., (2002) \\
\hline Sugarcane bagasse & Sodium bicarbonate & 196 & Junior et al., (2006) \\
\hline Bagasse fly ash & Hydrogen peroxide & 2.50 & Gupta and Ali (2004) \\
\hline Nipah palm shoot biomass & Mercaptoacetic acid & 52.86 & Wankasi et al., (2006) \\
\hline Bamboo (BVC) & Nitric acid & 57.71 & This work \\
\hline Bamboo (BVC) & Phosphoric acid & 30.19 & This work \\
\hline Common Buckwheat (FEMC) & Nitric acid & 56.49 & This work \\
\hline Common Buckwheat (FEMC) & Phosphoric acid & 14.08 & This work \\
\hline
\end{tabular}

\subsubsection{Temkin isotherm model}

The Temkin isotherm assumes that the heat of adsorption of all the molecules in a layer decreases linearly due to adsorbent-adsorbate interactions and that adsorption is characterized by a uniform distribution of binding energies, up to some maximum binding energy (Areco et al., 2010). The isotherm assumes that the fall in the heat of adsorption is linear rather than logarithmic as stated in Freundlich expression (Teles et al., 1993). Unlike the Langmuir and Freundlich equation, the Temkin isotherm takes into account the interactions between adsorbents and metal ions to be adsorbed and is based on the assumption that the free energy of sorption is a function of the surface coverage (Deng and Ting, 2005). The Temkin isotherm is applied in the following form 


$$
\mathrm{q}_{\mathrm{e}}=\frac{\mathrm{RT}}{\mathrm{b}_{\mathrm{T}}} \ln \left(\mathrm{A}_{\mathrm{t}} \mathrm{C}_{\mathrm{e}}\right)
$$

The linear form of Temkin equation is

$$
\begin{gathered}
q_{e}=\frac{R T}{b_{T}} \ln A_{T}+\frac{R T}{b_{T}} \ln C_{e} \\
q_{e}=\beta \ln \alpha+\beta \ln C_{e}
\end{gathered}
$$

Where, $\beta=\frac{\mathrm{RT}}{\mathrm{b}_{T}} ; \alpha=A_{T}$

$\mathrm{T}$ is the absolute temperature in Kelvin, $\mathrm{R}$ is the universal gas constant, $8.314 \mathrm{~J} / \mathrm{mol} \mathrm{K}, b_{T}$ is the Temkin constant related to heat of sorption $\left(\mathrm{J} \mathrm{mg}^{-1}\right)$ and $A_{T}$ the equilibrium binding constant corresponding to the maximum binding energy $\left(\mathrm{L} \mathrm{g}^{-1}\right)$. The Temkin constants $A_{T}$ and $b_{T}$ together with $R^{2}$ values are shown in Table 1.

The equilibrium data analyzed from the three-isotherm model as indicated in Table 1 shows that Frendulich isotherms fitted more precisely due to high correlation coefficient value $\left(R^{2}\right)$ then Langmuir and Temkin isotherm, this may be attributed to the heterogeneous distribution of the active sites and multilayer adsorption on the synthesized adsorbents (Gong et al., 2011; Liu and Wang, 2013).

\subsection{Effect of contact time}

The removal efficiency and adsorption capacity of the adsorbents increase sharply in the initial stage and then gradually remain steady with the increase of agitation time (Fig. 2). The initial fast adsorption may be attributed to large uncovered surface area of adsorbents. With further increase in the agitation time, the availability of the uncovered surface area gradually diminishes. The uptake was slower at the final phase due to the internal surface adsorption attaining plateau region at equilibrium (Aroua et al., 2008; Lo, 1999). The equilibrium was attained after shaking for 120 minutes. After equilibrium was attained, the percentage of sorption did not change with further increase in time. The decrease in the extent of removal of lead after 120 minutes of contact time in some cases may be due to the desorption process (Itodo et al., 2009).

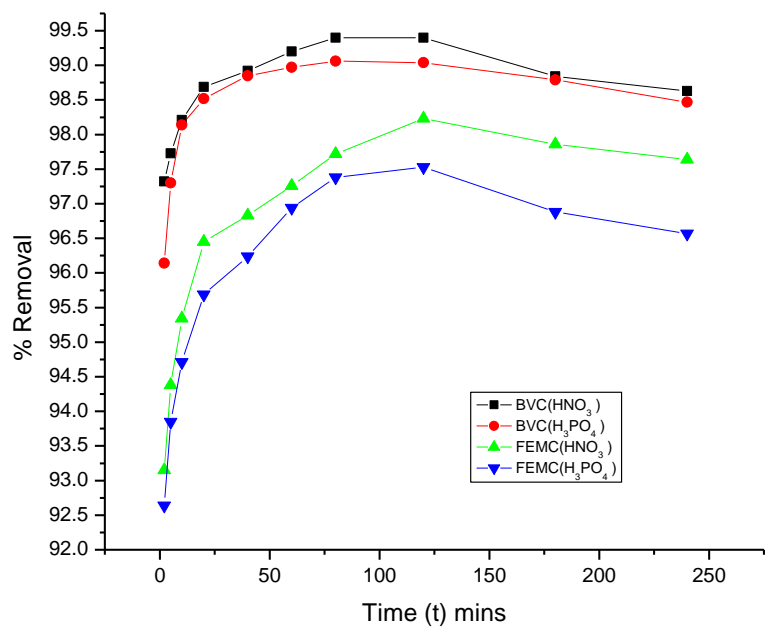

Figure 2. Effect of Contact time on percent removal of lead

\subsection{Adsorption kinetics}

One of the most important factors in designing an adsorption system is predicting the rate at which adsorption takes place, referred as the 'kinetics of sorption'. Three simplified kinetic models were adopted to examine the mechanism of the adsorptiov process.

\subsubsection{Pseudo first-order model}

Langergren and Svenska used rate equation to describe the adsorption of adsorbate from the liquid phase (Langergren \& Svenska, 1898); the linear form of pseudo first order rate expression is given as

$$
\log \left(q_{e}-q_{t}\right)=\log q_{e}-\frac{k_{1}}{2.303} t
$$

where $\mathrm{q}_{\mathrm{e}}$ and $\mathrm{q}_{\mathrm{t}}\left(\mathrm{mg} \mathrm{g}^{-1}\right)$ are the adsorption capacities of Lead(II) ions at equilibrium and at time $t$ (minutes), respectively, and $k_{1}$ is the rate constant of pseudo firstorder kinetics. The correlation coefficient $\left(R^{2}\right)$ and pseudofirst order constant $\left(k_{1}\right)$ for both adsorbents summarized in Table 3. The values of $R^{2}$ vary between $0.749-0.856$. The calculated values from the first-order kinetic model show that the experimental results did not fit this model. The determination co-efficient is very low for the given materials. Moreover, large differences between experimental and calculated values of the equilibrium sorption capacities are observed (Table 3).

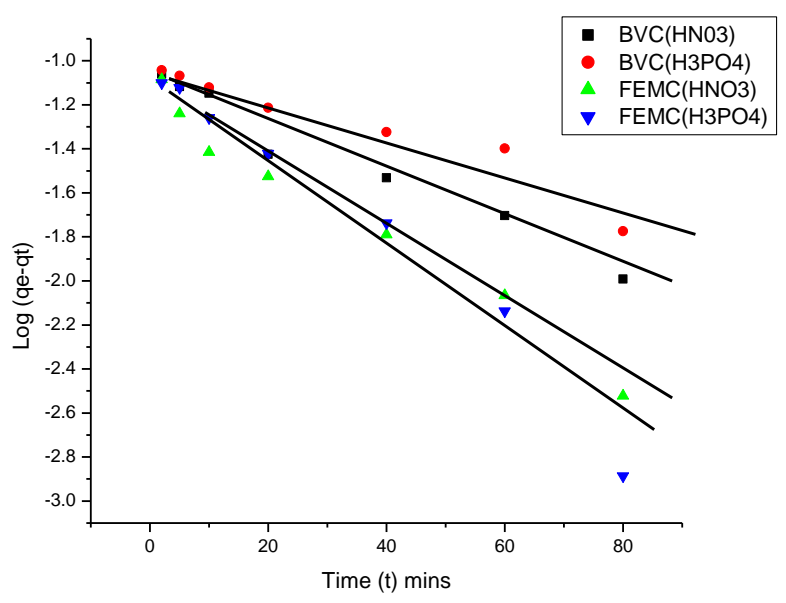

Figure 3. Pseudo-first order kinetic model fit for $\mathrm{Pb}$ (II) lons adsorption on the adsorbents

\subsubsection{Pseudo-second order model}

The pseudo second-order rate expression, which has been applied for analyzing chemisorptions kinetics from liquid solutions (Ho, 2006; Shrihari and Madhan, 2005), is linearly expressed as:

$$
\frac{t}{q_{t}}=\frac{1}{k_{2} q_{e}^{2}}+\frac{1}{q_{e}} t
$$

Where $k_{2}$ is the rate constant for pseudo second-order adsorption $\left(\mathrm{g} \mathrm{mg}^{-1} \mathrm{~min}^{-1}\right.$ ) and $\mathrm{k}_{2} \mathrm{qe}^{2}\left(\mathrm{mg} \mathrm{g}^{-1} \mathrm{~min}^{-1}\right)$ is the initial adsorption rate. The linear plot of $t / q t$ versus $t$, as shown in Fig. 4, shows a high linearity which yielded $R^{2}$ values that were greater than 0.999 for all adsorbents. 
Moreover, the calculated (cal) value of qe (Table 3) from the second-order kinetics was almost similar to the experimental (exp) values for all the adsorbents. Hence, it

Table 3. Comparison of different kinetic models

\begin{tabular}{|c|c|c|c|c|c|}
\hline \multicolumn{2}{|c|}{ ADSORBENT } & \multirow{2}{*}{$\begin{array}{c}\mathrm{BVC}\left(\mathrm{HNO}_{3}\right) \\
58.453\end{array}$} & \multirow{2}{*}{$\begin{array}{l}\text { BVC( }\left(\mathrm{H}_{3} \mathrm{PO}_{4}\right) \\
40.341\end{array}$} & \multirow{2}{*}{$\frac{\text { FEMC(HNO }}{30}$} & \multirow{2}{*}{$\frac{\text { FEMC }\left(\mathrm{H}_{3} \mathrm{PO}_{4}\right)}{24.234}$} \\
\hline & $q_{e}(\exp )\left(\mathrm{mg} \mathrm{g}^{-1}\right)$ & & & & \\
\hline \multirow[t]{3}{*}{ Pseudo-first-order } & $q_{e}(c a l)\left(m g ~ g^{-1}\right)$ & 45.231 & 23.544 & 12.782 & 9.562 \\
\hline & $k_{1}(1 / \mathrm{min})$ & 0.834 & 0.812 & 0.767 & 0.695 \\
\hline & $\mathbf{R}^{2}$ & 0.856 & 0.845 & 0.775 & 0.749 \\
\hline \multirow{3}{*}{$\begin{array}{l}\text { Pseudo-second- } \\
\text { order }\end{array}$} & $q_{e}(c a l)\left(m g ~ g^{-1}\right)$ & 56.870 & 37.345 & 27.678 & 22.986 \\
\hline & $k_{2}(1 / \mathrm{min})$ & 0.826 & 0.897 & 0.833 & 0.762 \\
\hline & $\mathbf{R}^{2}$ & 1 & 1 & 0.999 & 0.999 \\
\hline \multirow{3}{*}{$\begin{array}{l}\text { Intraparticle } \\
\text { diffusion } \\
\text { model }\end{array}$} & $k_{\text {id }}\left(\mathrm{mg} / \mathrm{g}^{-1} / \mathrm{min}^{1 / 2}\right)$ & 0.012 & 0.009 & 0.029 & 0.026 \\
\hline & $\mathrm{C}$ & 0.974 & 0.979 & 0.942 & 0.938 \\
\hline & $\mathbf{R}^{2}$ & 0.691 & 0.641 & 0.847 & 0.787 \\
\hline
\end{tabular}

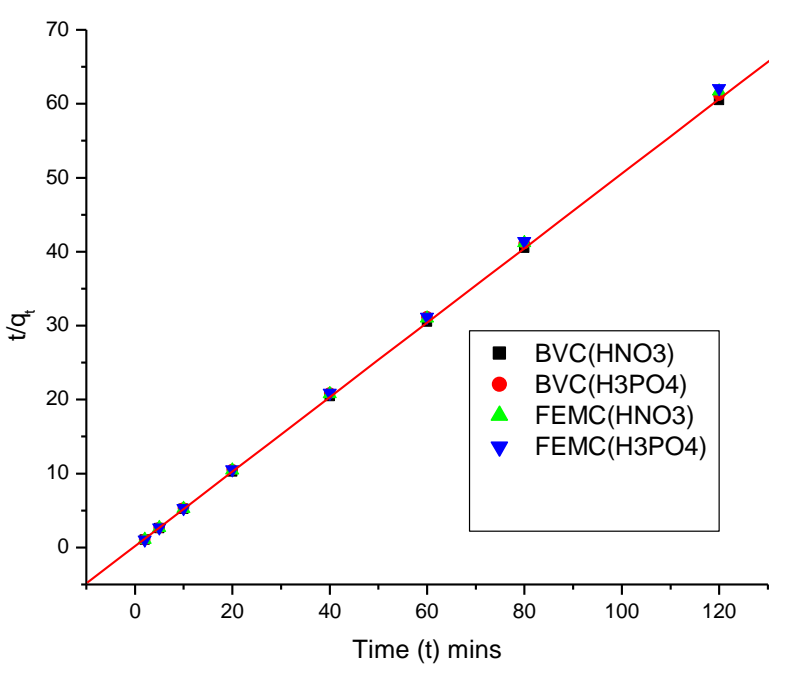

Figure 4. Pseudo-second order kinetic model fit for $\mathrm{Pb}$ (II) lons adsorption on the adsorbents

\subsubsection{Intraparticle diffusion model}

Intraparticle diffusion is a transport process involving the movement of species from the bulk of the solution to the solid phase. In a well stirred batch adsorption system, the intra-particle diffusion model has been used to describe the adsorption process occurring on a porous adsorbent (Webber and Morris, 1962; Ozacar and Sengil, 2005). According to Weber and Morris (1962), if the rate limiting step is intra-particle diffusion, a plot of solute adsorbed against the square root of the contact time should yield a straight line passing through the origin (Grente et al., 2007). Also, the rate constant for intra-particle diffusion is obtained from the slope of the curve. Weber and Morris, (1962) theorized that the rate of intra-particle diffusion varies proportionally with the half power of time and is expressed as:

$$
q_{t}=K_{i d}\left(t^{1 / 2}\right) C
$$

where, can be concluded that the adsorption for both adsorbents was predominated by pseudo-second order kinetic model. $\mathrm{q}_{\mathrm{t}}=$ adsorbate uptake at time $\mathrm{t},\left(\mathrm{mg} \mathrm{g}^{-1}\right)$

$\mathrm{K}_{\mathrm{id}}=$ the rate constant of intra-particle transport, ( $\left.\mathrm{mg} \mathrm{g}^{-1}-\mathrm{t}^{1 / 2}\right)$, which can be evaluated from the slope of the linear plot of $q_{\mathrm{t}}$ versus $t^{1 / 2}$.

The values of intercept, $c$ are related to the boundary layer thickness, i.e., the larger the value of the intercept, the greater is the boundary layer effect (Shrihari and Madhan, 2005; Webber and Morris, 1962). Fig. 5. shows the multilinearity in intra-particle diffusion plots for $\mathrm{Pb}(\mathrm{II})$ adsorption with different adsorbents. This indicates that intra-particle diffusion was not the only involved for $\mathrm{Pb}$ (II) adsorption, but there were some other processes involve in the rate controlling step. This suggests that adsorption occurred in three phases the initial steeper section represents surface or film diffusion; the second linear section represents a gradual adsorption stage where intraparticle diffusion is rate-limiting and the third section is final equilibrium stage. Thus, there were three processes controlling the adsorption rate.

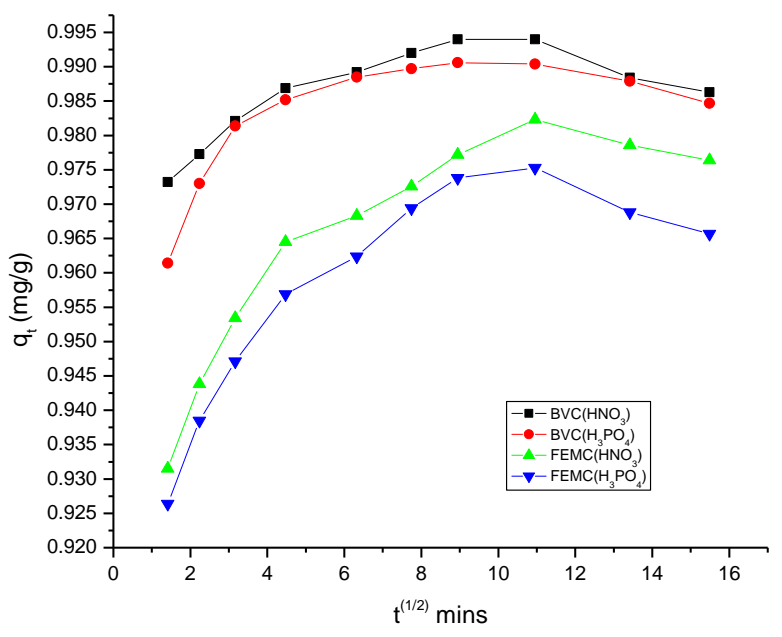

Figure 5. Intraparticle diffusion plots for the removal of lead by adsorption on various adsorbents 


\subsection{Effect of $p H$}

$\mathrm{pH}$ is one of the key parameters which controls the adsorption efficiency by influencing the surface charges (Kannan and Rengasamy, 2005). It is an important environmental factor influencing not only site dissociation, but also the solution chemistry of the heavy metals: hydrolysis, complexation by organic and inorganic ligands, redox reactions and precipitation. It strongly influences the speciation and adsorption availability of heavy metals (Esposito et al., 2002).

The effects of initial $\mathrm{pH}$ on lead solution were investigated by varying the $\mathrm{pH}$ from 2 to 5.5 and using initial lead concentration of $20 \mathrm{mg} \mathrm{L}^{-1}$ in $100 \mathrm{ml}$ of lead solution with $1 \mathrm{~g}$ of adsorbent. The Lead adsorption usually increases as the $\mathrm{pH}$ is increased attaining optimum capacity at $\mathrm{pH}: 5.5$ (Shukla et al., 2002; Jalali et al., 2002). Above pH 5.5, Pb(II) starts precipitating as $\mathrm{Pb}(\mathrm{OH})_{2}$ and hence studies above this range are not conducted (Patnukao et al., 2008).

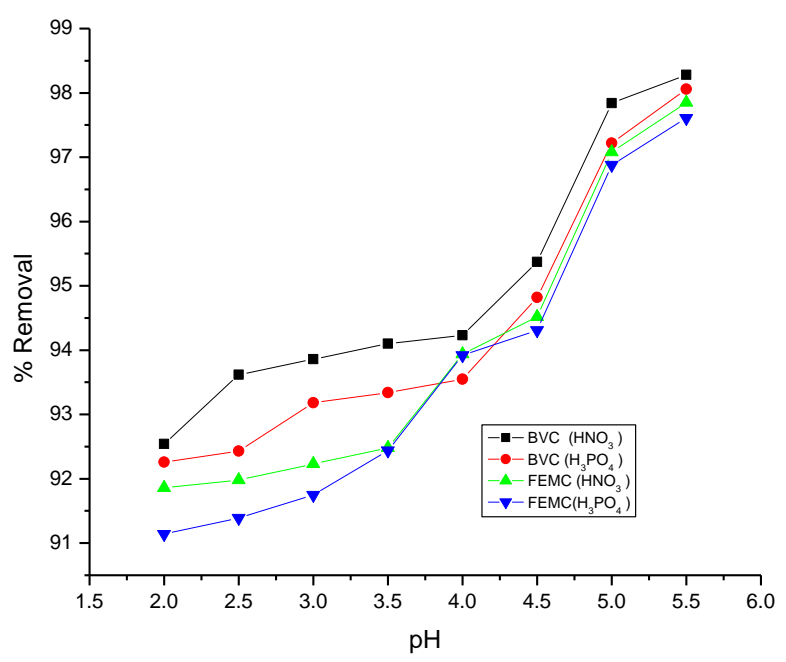

Figure 6. Effect of $\mathrm{pH}$ on percent removal of Lead.

\section{Conclusions}

Adsorption studies of lead on activated carbons was studied by batch method where effect of initial concentration, contact time and $\mathrm{pH}$ were the parameters considered for determining the adsorption efficiency of the synthesized carbon samples. The results of the percentage removal of lead increased with the increase of contact time and $\mathrm{pH}$. On the contrary, the percentage of removal decreased with the increase in initial concentration of the standard lead solution. The equilibrium data was analyzed using Langmuir, Freundlich and Temkin adsorption isotherms. Freundlich isotherm displayed a better fitting model than the other two models with a higher correlation coefficient of 0.999 to 0.991 indicating a multilayer adsorption. Four adsorption kinetic models were studied, the pseudo second- order kinetic model accurately described the adsorption kinetics. The results show intraparticle diffusion was not the only rate limiting factor in adsorption of $\mathrm{Pb}$ (II) ions. The adsorption mechanism was found to be chemisorption and the rate-limiting step was mainly surface adsorption. Results from this study shows that both the adsorbents are very effective in the removal of Lead (II) ions. However, surface modification using $\mathrm{HNO}_{3}$ gave a better result as compared to $\mathrm{H}_{3} \mathrm{PO}_{4}$. This suggests that surface modification using $\mathrm{HNO}_{3}$ leads to the formation of more well-defined pores of different shapes and size attributing to its high surface area which trap more metal ions within the adsorbent. The novelty about these bio-adsorbents is that the raw materials used are readily available almost throughout the year, inexpensive and user-friendly.

\section{Acknowledgements}

The authors acknowledge the staff of SAIF, NEHU Shillong for providing necessary laboratory facilities for analyzing lead samples.

\section{References}

Acharya J., Sahu J.N., Mohanty C.R. and Meikap B.C. (2009), Removal of lead (II) from wastewater by activated carbon developed from Tamarind wood by zinc chloride activation, Chem. Eng. J, 149, 249- 262.

Areco M.M. and Afonso M.S. (2010), Copper, zinc, cadmium and lead biosorption by Gymnogongrus torulosus: thermodynamics and kinetics studies, Biointerfaces, 81, 620628.

Aroua M.K., Leong S.P.P., Teo L.Y., Yin C.Y.W. and Daud W.M.A. (2008), Real-time determination of kinetics of adsorption of lead(II) onto palm shell-based activated carbon using ion selective electrode, Bioresour. Technol, 99, 5786-5792.

Bahadir T., Bakan G., Altas L. and Buyukgungor H. (2007), The investigation of lead removal by biosorption-An application at storage battery industry wastewaters, Enzyme Microb. Technol, 41, 98-102.

Bhattacharjee S., Chakrabarty S., Maity S., Kar S., Thakur P. and Bhattacharyya G. (2003), Removal of lead from contaminated water bodies using sea nodule as an adsorbent, Water Res, 37, 3954-3966.

BIS (1981), Tolerance limits for industrial effluents prescribed by Bureau of Indian Standards. IS - 2490(Part I), New Delhi .

Bohumil Volesky (1990), Biosorption of heavy metals, CRC press, Inc; Boca Raton, Florida.

Chen J.P. and Wu S. (2004), Acid/base-treated activated carbons: characterization of functional groups and metal adsorptive properties, Langmuir, 20, 2233.

Connell D.W.O., Birkinshaw C. and O' Dwyer T.F. (2008), Heavy metal adsorbents prepared from the modification of cellulose: A review, Bioresour. Technol, 99, 6709-6724.

Crini G., Peindy H.N., Gimbert F. and Robert C. (2007), Removal of C.I. Basic Green 4 (Malachite Green) from aqueous solutions by adsorption using cyclodextrin-based adsorbent: Kinetic and equilibrium studies, Sep. Purif. Technol, 53, 97-110.

Deng S.B. and Ting Y.P. (2005), Fungal biomass with grafted poly (acrylic acid) for Enhancement of $\mathrm{Cu}(\mathrm{II})$ and $\mathrm{Cd}(\mathrm{II})$ biosorption, Langmuir, 21, 5940-5948.

Doyurum S. and Celik A. (2006), $\mathrm{Pb}(\mathrm{II})$ and $\mathrm{Cd}(\mathrm{II})$ removal from aqueous solutions by olive cake, J. Hazard. Mater, 138, 22-28.

Esposito A. and Pagnanell F. and Veglio F. (2002), pH-related equilibria models for bio Sorption in single metal systems, Chem. Eng. Sci, 57, 307-313.

Feng Q., Lin Q., Gong F., Sugita S. and Shoy M. (2004), Adsorption of lead and mercury by rice husk ash, J. Colloid Interf. Sci, 278, 1-8. 
Ferro-Garcia M.A., Rivera-Ultrilla J. and Bautista-Toledo I. (1988), Adsorption of zinc, cadmium and copper on activated carbons obtained from agriculture bio products, Carbon, 28, 363-373.

Freundlich H. and Helle W.J. (1939), Ubber die adsorption in Lusunge, J. Am. Chem. Soc, 61, 2-28.

Gong J., Liu T., Wang X. and Zhang L. (2011), Efficient removal of heavy metal ions from aqueous systems with the assembly of anisotropic layered double hydroxide nanocrytals at carbon nanosphere, Environ. Sci. Technol, 45, 6181-6187.

Gupta V.K. and Ali I. (2004), Removal of lead and chromium from wastewater using bagasse fly ash - a sugar industry waste, J. Colloid Interface Sci, 271, 321-328.

Gupta V.K., Agarwal S. and Saleh T.A. (2011), Synthesis and characterization of alumina-coated carbon nanotubes and their application for lead removal, J. Hazard. Mater, 185, 17-23.

Gupta V.K., Jain C.K., Ali I., Sharma M. and Saini V.K. (2003), Removal of cadmium and nickel from wastewater using bagasse fly ash - a sugar industry waste, Water Res, 37, 4038-4044.

Ho Y.S. (2004), Citation review of Lagergren kinetic rate equation on adsorption reactions, Scientometric, 59, 171-177.

Itodo A.U., Abdulrahma F.W., Hassan L.G. and Maigandi S.A. (2009), Happiness UO. Diffusion mechanism and kinetics of Biosorption of textile dye by $\mathrm{H}_{3} \mathrm{PO}_{4}$ and $\mathrm{ZnCl}_{2}$ impregnated poultry wastes sorbents, International Journal of Natural and Applied sciences, 5(1), 7-12.

Jalali R., Ghafouria H., Asef Y., Davarpanah S.J. and Sepehr S. (2002), Removal and recovery of lead using non-living biomass of marine algae, J Hazard Mater, 92, 253-262.

Junior O.K., Gurgel L.V.A., de Melo J.C.P., Botaro V.R., Melo T.M.S., de Freitas Gil R.P. and Gil L.F. (2006), Adsorption of heavy metal ion from aqueous single metal solution by chemically modified sugarcane bagasse, Bioresour. Technol, 98, 1291-1297.

Kannan N. and Rengasamy G. (2005), Comparison of cadmium ion adsorption on various activated carbons, Water air soil pollut, 163, 185-201.

Langergren S. and Svenska B.K. (1898), Zur theorie der sogenannten adsorption geloester stoffe, Handlingar, 24, 1-39.

Langmuir I. (1918), "The Adsorption of Gases on Plane Surface of Glass,mica and Platinum", The Research Laboratory of the General Electric, J. Amer. Chem. Soc, 40, 1361-1403.

Li Q., Zhai J., Zhang W., Wang M. and Zhou J. (2006), Kinetic studies of adsorption of $\mathrm{Pb}(\mathrm{II}), \mathrm{Cr}$ (III) and $\mathrm{Cu}$ (II) from aqueous solution by sawdust and modified peanut husk, J. Hazard. Mater, B 141, 163-167.

Liu J. and Wang X. (2013), Novel silica-based hybrid adsorbents: Lead(II) adsorption isotherms, Sci.World J, article 897159.

Lo W., Chua H., Lam K.H. and Bi S.P. (1999), A comparative investigation on the biosorption of lead by filamentous fungal biomass, Chemosphere, 39(15), 2723-2736.

Low K.S., Lee C.K. and Liew S.C. (2000), Sorption of cadmium and lead from aqueous solutions by spent grain, Process Biochem., 36, 59-64.

Mall I.D., Srivastava V.C., Kumar G.V.A. and Mishra I.M. (2006), Characterization and utilization of mesoporous fertilizer plant waste carbon for adsorptive removal of dyes from aqueous solution, Colloids Surfaces A: Physicochem. Eng. Aspects, 278, 175-187.
Meeenakshi S. and Viswanathan N. (2007), Identification of selective ion exchange resin for lead (II) ions sorption, J. Colloid Interface Sci, 308, 438-450.

Montanher S.F., Oliveira E.A and Rollemberg M.C. (2005), Removal of metal ions from aqueous solutions by sorption onto rice bran, J. Hazard. Mater, B117, 207-211.

Nadeem M., Nadeem R., Nadeem H.U. and Shah S.S. (2005), Accumulation of lead and cadmium in different organs of chicken, Pak. J. Sci. Res, 57,71-82.

Netzer A. and Hughes D.E. (1984), Adsorption of copper, lead and cobalt by activated carbon, Water Res, 18, 927.

Noeline B.F., Manohar D.M. and Anirudhan T.S. (2005), Kinetic and equilibrium modeling of lead(II) sorption from water and wastewater by polymerized banana stem in a batch reactor, Sep. Purif. Technol, 45, 131-140.

Özacar M. and Sengil I.A. (2004), Equilibrium data and process design for adsorption of disperse dyes onto alunite, Environ. Geol, 45, 762-768.

Özacar M. and Sengil I.A. (2005), A kinetic study of metal complex dye sorption onto pine sawdust, Process Biochem, 40, 565-572.

Patnukao P., Kongsuwan A. and Pavasant P. (2008), Batch studies of adsorption of copper and lead on activated carbon from Eucalyptus camaldulensis dehn. Bark, J. Environ. Sci, 20, 1028-1034.

Ricordel S., Taha S., Cisse I. and Orange G. (2001), Heavy metals removal by adsorption onto peanut husks carbon: Characterization, kinetic study and modeling, Sep. Purif. Technol, 24, 389-401.

Saeed A., Iqbal M. and Akhtar M.W. (2005), Removal and recovery of lead(II) from single and multimetal ( $\mathrm{Cd}, \mathrm{Cu}, \mathrm{Ni}, \mathrm{Zn})$ solutions by crop milling waste (black gram husk), J. Hazard. Mater., 117, 65- 73.

Sekar M., Sakthi V. and Rengaraj S. (2004), Kinetics and equilibrium adsorption study of lead(II) onto activated carbon prepared from coconut shell, J. Colloid Interf. Sci, 279, 307-313.

Shrihari V., Madhan S. and Das A. (2005), Kinetics of phenol sorption by Raw agrowastes, Applied Sciences, 6(1),47-50.

Shukla A., Zhang Y.H., Dubey P., Margrave J.L. and Shukla S.S. (2002), The role of sawdust in the removal of unwanted materials from water, J. Hazard. Mater, 95(1-2), 137-152.

Sohail A. and Qadeer R. (1997), Kinetic study of lead ion adsorption on activated carbon, Adsorp. Sci. Technol, 15, 815.

Somasekhara Rao, Emmanuel K.A. and Ravi M. (2011), Activated Kaza's carbons and removal of $\mathrm{Pb}, \mathrm{Mn}$ from $\mathrm{H}_{2} \mathrm{O}$. Lambert Academic Publishers Germany.

Taty-Costodes V.C., Fauduet H., Porte C. and Delacroix A. (2003), Removal of $\mathrm{Cd}(\mathrm{II})$ and $\mathrm{Pb}$ (II) ions from aqueous solutions by adsorption onto sawdust of Pinus sylvestris, J. Hazard. Mater., B 105, 121-142.

Teles de Vasconcelos L.A. and Gonzalez Beca C.G. (1993), Adsorption equilibria between pine bark and several ions in aqueous solution $\mathrm{Cd}(\mathrm{II}), \mathrm{Cr}(\mathrm{III})$ and $\mathrm{Hg}(\mathrm{II})$, Eur. Water Pollut. Control, 3, 29-39.

Temkin M.J. and Pyzhev V. (1940), Kinetics of ammonia synthesis on promoted iron catalysts, Acta Physiochim USSR, 12, 217-222.

Tiemann K.J., Gamez G., Dokken K., Parsons J.G. and GardeaTorresdey J.L. (2002), Chemical modification and X-ray 
absorption studies for lead(II) binding by Medicago sativa (alfalfa) biomass, Microchem. J., 71, 287-293.

Tong S. (1998), Lead Exposure and Cognitive Development: Persistence and a Dynamic Pattern, Journal of Paediatric Child Health, 34(2), 114-118.

Wankasi D., Horsfall Jr. M. and Spiff A.I. (2006), Sorption kinetics of $\mathrm{Pb}^{2+}$ and $\mathrm{Cu}^{2+}$ ions from aqueous solution by Nipah palm (Nypa fruticans Wurmb) shoot biomass, Elec. J. Biotechnol, 9, 587-592.

Weber W.J. and Morris C.J. (1962), Advances in water pollution research: removal of biologically resistant pollutants from waste water by adsorption, Pergamon Press, 2, 231-266.

Wong K.K., Lee C.K., Low K.S. and Haron M.J. (2003), Removal of $\mathrm{Cu}$ and $\mathrm{Pb}$ from electroplating wastewater using tartaric acid modified rice husk, Process Biochem, 39, 437-445. 